\title{
Human Thought, Language, and Culture: Pakpak Simsim Language Application in Psycholinguistic Overview
}

\author{
Isnaeni Diah ${ }^{1}$, Kaulika Fella ${ }^{2}$, Sari Fhadilah ${ }^{3}$, Octavianti Sri $^{4}$ \\ \{diahmutiaraisna@gmail.com¹, kaulikafella2@gmail.com², fitrifhadilah@gmail.com³ \\ srioctavianti@gmail.com ${ }^{4}$ \} \\ 1,2,3,4 Magister Ilmu Linguistik, Universitas Sumatera Utara lingusitik.usu.ac.id
}

\begin{abstract}
This study aims to investigate the relation among human thought, language and culture in Pakpak Simsim language. This study tends to analyze the production of linguistic forms in human thought that are applied in Pakpak Simsim language as realized in their daily life and relate it to the culture existed. The findings show that the language used by Pakpaknese are influenced by the characters of the people. Syntax elements that are built by them during constructing sentences prove that they tend to be such objective person because the pattern they use is Verb-Subject-Object-Complement. This finding also implies that Pakpaknese is straight-forward people that only speak up to the pointly while having conversation with others.
\end{abstract}

Keywords: Pakpak Simsim, Human thought, Language, Culture, Psycholinguistic

\section{Introduction}

Linguistics is a science that studies language [1]. Language in linguistic context is seen as an arbitrary, conventional sound system and used by humans as a means of communication. This means that linguistics in general does not associate language with other phenomena. Language is seen as a language that has a unique and unique structure. That is why language can blend with other disciplines such as sociology, anthropology, etc. [2] encourage people to learn language through several aspects such as individual's motivation, personality, content and context, as well as learner's beliefs on their communication competence.

One of the disciplines that combine with linguistics is psychology. After mixing, both of them become one linguistic study, psycholinguistics. In Harras, Bachari stated that etymologically, the term Psycholinguistics comes from two words, namely Psychology and Linguistics [3]. The two words each refer to the name of a scientific discipline. In general, Psychology is often defined as the study of human behavior by examining the nature of stimulus, the nature of response, and the nature of thought processes before the stimulus or response occurs. Psychologists now tend to think of psychology as a science that examines human thought processes and all their manifestations that govern human behavior. The purpose of studying the thought process is to understand, explain, and predict human behavior. Further, Lavelt in [4] stated that psycholinguistics is the study of the use and of acquisition of human language and also it consists of different aspects. The first is acquisition. It relates to how the human (especially children) learn the language. The second is the use of language by normal adults".

At first the term used for psycholinguistics was linguistic psychology (linguistic psychology) and there were also those who referred to it as psychology of language. Then as a 
result of more directed and systematic cooperation, a new science was born which was later called psycholinguistics (psycholinguistics).

Studies in psycholinguistics are also of course quite extensive, one of which is the study of thinking relationships with languages. Sapir and Whorf, Edward Sapir was a 20th century American scholar (1884-1939) he explained the relationship between language and thinking. His opinion is almost the same as the opinion of Van Boldt, he said that humans live in this world under the mercy of their language which has become a means of delivery in their society. As much as that is the language of the world community as much as the world is formed by those languages for its speakers [5]. As the additional, [6] stated that the main logical frames in language application of human life is perceptible.

According to Whorf as well as Von Humboldt and the sapir of language determine one's thoughts until sometimes this endangers themselves. Piaget's theory of cognitive growth has been explained that language forms the human mind. Language determines how we think. The third theory says that the opposite is true; thoughts form languages without language thoughts there will be no thoughts that determine the syntactic aspects of how sentences are arranged and lexicons of language, not vice versa.

This piaget theory is the basis of this group's research. As it is known that North Sumatra is one of the provinces in Indonesia which has a variety of tribes and cultures, they are Batak, Javanese, Malay, Minang, and other tribes that are rarely heard by the general public. The great diversity of tribes possessed by North Sumatra makes this province thick for its cultural customs.

One entity that is included in culture is language. Language is used as a communication tool so that the information conveyed by the speaker can be conveyed properly by the listener. Through language we can also know the characteristics of an area. With so many tribes scattered in the North Sumatra region, the language used in daily life also varies depending on where the person lives.

There is a tribe in North Sumatra that attracts the attention of researchers because it is rarely known to the general public but $90 \%$ of the population is still a native of the tribe. The tribe is the Pakpak tribe. The Pakpak are a Batak sub-tribe. This tribe inhabits a district called Pakpak Bharat Regency. The Regency was formed on July 28, 2003 and is the result of the division of Dairi Regency. The Pakpak tribe itself consists of five asylum, namely Suak Simsim, Keppas, Pegagan, Boang, and Kelasen. Each suak has a variety of languages based on their respective asylum names and is distributed in the area around Pakpak Bharat Regency. Suak Simsim uses the Pakpak Simsim language which is most widely used in the Pakpak Bharat District. Suak Keppas uses the Pakpak Keppas language and is usually used in Dairi Regency. Suak Pegagan uses the Pakpak Pegagan language and its usage area in parts of Samosir Regency. Suak

Boang uses the Pakpak Boang language and is commonly used in the City of Subulussalam (Aceh). Finally, Suak Classen uses Pakpak Kelasen language, the area of use is in Humbang Hasundutan Regency.

Because the majority of the population of Pakpak Bharat Regency uses Pakpak Simsim Language, this research will examine Pakpak Simsim language. Esser in Ermanto states that the Pakpak Simsim language is included in the Gayo language family and is an etymon of the Austronesian Proto language. Thus, in its application Pakpak Simsim Language is similar to Gayo language because they are still allied.

Therefore, The object of this article's research is Pak Simsim's language. This research believes that the language Pak Pak adheres to by society is a reflection of the mindset and behavior of the speaking community. The data obtained is the result of interviews with 
informants who are native people of Pak Simsim's tribe. In addition to enriching the linguistic and psycholinguistic knowledge of this research, this study also wants to make readers more familiar with Indonesian cultural ethnics that are equally good compared to other ethnic groups.

\section{Theoretical Foundation}

\subsection{Language}

Language is a unique structure possessed by humans. Without language humans cannot communicate perfectly and without communication this world will be chaotic. Because the importance of language for humans, the language must be studied scientifically, so that it can be used as well as possible and utilized as much as possible. That the science that studies language is scientifically named linguistics. So psycholinguistics as a part of linguistics is a science that tries to examine scientifically the nature of language, the structure of language, how language is born, how language is acquired and culture and thinking.

Van Humboldt's theory which has the full name of Wilhelm Von Hamboldt he is a 19th century German scholar said the following statement:

"Humans live with things in particular, because their feelings and behavior depend on their input and observers, so they are said to be entirely - just as the language affects them. With the same process as he took the language out of him he doubled himself in that language; and each language opens a magic circle encircling a person who has that language, one circle and he cannot be released unless he steps out and enters another circle (Humboldt, 1830-1838, VII: $60) "$.

\subsection{Language and Cultural Relations}

Benjamin Lee whorf (1897-1941) the student of Sapir after studying several Indian tribal languages, such as the Aztec language in Mexico and especially the hopi language in California and this is related to his own experiences while working as a refinery fire prevention expert. According to the classical view, language and thinking of each stand alone, now this view becomes a modern view.

According to Whorf as well as Von Humboldt and the sapir of language determine one's thoughts until sometimes this endangers themselves. About the language of Hopi Whorf also gave birth to a theory of relativity which is now famous with the name of the whorf hypothesis and sometimes associated with the name of the teacher being the hypothesis of Sapir-Whorf.

These conditions are absolute; we cannot speak at all, unless we all accept and obey the organization and classification of the data outlined by this agreement [7] that the habit of language-language has presented the falsehood of facts to human speakers, has been proven by Whorf with one example, namely the state of tin 'empty' but can still explode as explained above.

\subsection{Language Relationships with Thinking}

Linguistic Relativity Theory: Sapir and Whorf, Edward Sapir was a 20th century American scholar (1884-1939) he explained the relationship between language and thinking. His opinion is almost the same as the opinion of Van Boldt, he said that humans live in this world under the mercy of their language which has become a means of delivery in their society. As much as that is the language of the world community as much as the world is formed by those languages for its speakers [5].

If it is talking about thingking, it will be surely related to the perception. [8] stated that perception is an internal process to select, evaluate and organize stimuli from the external 
environment. An individual perception on objects, events or relationships is obtained by inferring information and determine the message. The process involves the interpretation process based on the experience of an event or object. Because whenever people thinking, the perception is also implied in it.

Piaget's theory of cognitive growth has been explained that language forms the human mind. Language determines how we think. The third theory says that the opposite is true; thoughts form languages without language thoughts there will be no thoughts that determine the syntactic aspects of how sentences are arranged and lexicons of language, not vice versa. The main pioneer of this third theory is a well-known French scholar named Jean Piaget, who argues that if a child can classify a group of objects in different ways, before the child can classify the objects using words that similar to these enda-things, Growth cognition is a process of thinking and knowledge can be explained or may occur before language development. This theory is often named according to Piaget's teaching the theory of cognitive growth [9].

Regarding the relationship between language and the operations of the intellect in the future, Piaget repeatedly stated two important things as touched briefly:

1. The source of intellect operations is in language but in the sensorimotor period (a period of joyful motorbikes) that is, a schema system is fully developed and prepares images of the various aspects of the structure and the relations of objects ( before or before other images) and basic forms of storage and reuse operations.

2. The formation of thoughts that can be put forward and shaped takes place at the same time as the acquisition of language, both of which belong to a more general process, it is a constitutional function symbol in general. This symbol function has several aspects. The beginning of the function symbol is characterized by various behaviors that occur simultaneously in its development.

The words of the first language come out very closely and occur simultaneously with the play of symbols, imitation and mental images.

\section{Discussion}

\subsection{Sentence Structure Analysis}

In this section, we will discuss thinking, culture, and language relations based on the sentence structure which formed by the Pakpaknese society when they utter an information through syntax structure. As has been stated by Landau syntax is structural case [10], which is assigned/checked in certain configurations of linguistic construction. Therefore, these below explanation is laid based on its syntax.

\section{Sentence}

To understand sentence structure is the basic thing that we should have in studying language [11]. Sentence is a part of language which relatively independent. It has structure of final intonation, and in form or still potential consist of clause; independent clause that can be part of cognitive in a conversation; construction that is a combination of a clause, that can form independent form; brief answer, imperative, greetings, and such. In Badudu stated that as a construction, sentence should has structure and content [12]. Structure in a sentence is to create a meaning. It consists of words that is constructed by sentence rules. Content of a sentence is the idea that built by the content concept in words. Every element in a sentence should be in proper place, not only proper place, but also has clear relation toward each other words. 
There are some kind of sentence according to Tarigan [13] a) total and kind clause that is found in base, b) structure of internal main clause, c) kind of expected response, d) characteristics of actor-action relationship, e) exist or not negative element in main verb phrase, f) the simple and completed base, g) position in a conversation, and h) context and given answer. As brief classification, total kind of clause, it consists of simple sentence, compound sentence, complex sentence. Based on its structure of internal main clause, it is divided in to full sentence and minor sentence. From response side, sentence is divided into question sentence, statement sentence, and imperative sentence. Based on actor and action relationship, it is divided into active sentence, passive sentence, medial sentence, and reciprocal sentence. From its negative, sentence is divided become affirmative and negative sentence. Based on its complete and simplicity, it is well-formed sentence, transform sentence, and incomplete sentence. In its position in a conversation, it is divided become situational sentence, sequence sentence, and response sentence. Based on context and given answer, they are greetings sentence, call sentence, exclamation, question, request, and statement.

In Bahasa [14] mention that there are some elements of function, category, and role in a sentence. Besides, sentence has structure that most likely well known as subject, verb (predikat) , object, adverb, and complement. There are six kind of sentence structure :
(1) S-P
(Orang itu sedang tidur)
(2) S-P-O ( Ayah membeli mobil baru)
(3) S-P-Pel (Zikri menjadi ketua kelas)
(4) S-P-Ket ( Kamil Tinggal di Jogja)
(5) S-P-O-Pel
( Dia mengirimi ibunya uang)
(6) S-P-O-Ket
( Beliau memperlakukan kami dengan baik)

\section{Subject}

According to Halliday $(1988,35)$, subject is kind of grammatical term in the component of a sentence. In syntax subject. Subject is element of sentence that has function as main actor in a sentence [15]. Generally, according to Putrayasa subject can be as a form of noun, phrase, or everything that classified as noun [16]. Subject has some some characteristics :

(1) It can be the answer of what or who

To determine a subject in a sentence can be done by looking for an answer to question what and who. Question of who is usually used to determine subject in a sentence that can be person, while question what is used to non-person.

(2) Using word, it

Itu is a sign of subject, it usually has general characteristics.

(3) Always start with bahwa

Bahwa in passive sentence is used as a sign of subordinate clause to fulfill subject position.

(4) Has word yang

Word that become subject in a sentence can be given further explanation that used conjuction yang.

(5) Not started with preposition 
Subject can not began with preposition like to, from, in, on, as, about, for, and etc.

\section{Predicate}

Predicate or verb is element in sentence that has function to explain subject [15]. The absence of subject can cause unclear meaning in a sentence. There are some characteristics of verb/predicate:

(1) Answer on question why and how

Part in a sentence that gives information on question why and how is predicate in a sentence.

(2) followed by adalah and ialah

Predicate in a sentence can be adalah and ialah. This kind of predicate is predicate that usually called as nominal sentence.

(3) Can be a negation

Predicate in a sentence in Bahasa has negation form that shown by no or not. Beside no or not, a sign of predicate can also be a noun. (4) Can be followed by aspects and modality

Sentence predicate can be a verb or adjective can be followed by aspect words such as telah, sudah, belum, akan, and sedang. Sentence that has person as subject can be followed by modality, words that stated action of speaker such as ingin, hendak, and mau.

\section{Object}

Putrayasa stated that object is element that its existence is because of transitive verb as predicate in active sentence [16]. Object is always placed after predicate. It can be opposed by subject. This element is very important for verb that started with prefix me-. It can not be found in passive sentence or intransitive verb. Some characteristics of object :

(1) It can be only for noun

(2) Placed after predicate for transitive verb

(3) Can be a subject in passive sentence

(4) It can be replaced with -nya

(5) Not began by preposition

\section{Introgative Sentence}

Basically, question word has function to replace something that want to know by speaker or to emphasize what speaker want to know [14]. stated that there are some kinds of function from interrogative sentence :

(1) To ask about noun as person by using who or siapa.

(2) To ask about noun but not a person by using what or apa

(3) To ask something about person, stuff, or something that used by using which or mana

(4) To ask about the reason by using why or kenapa

(5) To ask about time by using When or kapan

(6) To ask about condition or way of doing something by using how or bagaimana

(7) To ask about number or amount of something by using how much berapa. 
Kridalaksana [17] added that there are eight functions of interrogative sentence. It stated that to emphasize a preposition in a sentence. Alwi [14] stated that interrogative sentence construction is determined by the word that used by the speaker. The position of this question word can be moved without resulting any change.

Interrogative sentence that used question word like who, what that replaced obligatory position in a sentence result the change of sentence structure if moved to front position. So it means in an interrogative sentence question word is not necessarily always be in front. Example:

Siapa yang dia cari?

The sentence has sentence structure P-S. The sentence above has predicate on siapa and yang dia cari as predicate. For why or mengapa, the structure will be, example:

Mengapa Anda tidak hadir?

The sentence has structure K-S-P. Mengapa as K, Anda as S, and tidak hadir as P. The question word mengapa can be changed its position, like for example:

Anda mengapa tidak hadir?

The sentence above still has the same component as the first sentence, the meaning also does not change even if the position has changed. For question word where or di mana, example:

Di mana pengusaha itu bertempat tinggal?

For the sentence above has structure Di mana as $\mathrm{K}$, pengusaha itu as $\mathrm{S}$, bertempat tinggal as $\mathrm{P}$. so, the structure of the sentence is K-S-P. The sentence above can have different position of question word without changing its meaning, example:

\section{Buatan mana sepeda itu?}

The structure of the sentence is $\mathrm{P}$ for Buatan, mana as $\mathrm{K}$, and sepeda itu as S. Even if the question word is moving but the meaning is still the same [18].

Some question word that have been explained above, generally replace certain function in interrogative sentence for example function S-P-O-K. Most part in the question words can ask the obligatory element in an interrogative sentence. It means question words that already distributed above should be presented in an interrogative sentence so it will be acceptable [14].

\section{Negative Sentence}

In Bahasa, negative sentence always has strong relation with negative constituent. The negative constituent itself is usually called as negation. Sudaryono [19] stated that negative constituent act as qualifierfor verb or other constituent as predicate as a clause or sentence. As a qualifier, negative constituent never take position as the core of sentence. It only takes place to fulfill other syntax function. In this case, negative constituent most likely as negation toward other constituent.

According to Sudaryono [19] negative constituent in Bahasa is tidak and bukan. Rasul [20] mentioned that there are some other negative constituent such as tanpa, belum, jangan, and tiada. Howard (2000) stated that in negation the negative constituent follows the verb that come after them. They are a predicate in a sentence. Example:

Saya bukan kepala sekolah 
In this example according to Sudaryono [19] the sentence above is negation. The negative constituent that appeared is bukan. It has structure that how negation can be implemented in to base sentence which has one clause and single predicate.

\section{B. Sentence Structure of Pakpak Simsim Language}

There are some kind of sentence structure in Pakpak language [21] as follow:

(1) Subject-Predicate Example:

$\begin{array}{lll}\text { Manuk kabang } & \text { Ayam terbang } & \text { S-P } \\ \text { Bapa Laus } & \text { Ayam pergi } & \text { S-P } \\ \text { Ia mangan } & \text { Dia makan } & \text { S-P }\end{array}$

(2) Subject-Predicate-Object Example:
Ia laus mi sabah
Dia pergi ke sawah
S-P-O
Kalak i main bola
Mereka bermain bola
S-P-O
Inang letja karejo
Ibu capek bekerja
S-P-O

(3) Predicate-Subject Example:

$\begin{array}{lll}\text { Tellu kalaki } & \text { Bertiga kami } & \text { P-S } \\ \text { Roh family } & \text { Datang tamu } & \text { P-S } \\ \text { La us ia } & \text { Pergi dia } & \text { P-S }\end{array}$

(4) Subject-Predicate-Keterangan (Adverb) Example:

$\begin{array}{lrr}\text { Bapa ndungo cekge } & \text { Ayah bangun pagi } & \\ \text { Ia laus bari } & \text { Dia pergi semalam } & \text { S-P-K } \\ \text { Kaka merdahan i dapur Kakak memasak di dapur } & \text { S-P-K }\end{array}$

(5) Keterangan (Adverb)-Subject-Predicate Example:

$\begin{array}{lll}\text { Ijuma bapa karejo } & \text { Di ladang ayah bekerja } & \text { K-S-P } \\ \text { Cekgen-cekgen kalak meridi } & \text { Pagi-pagi mereka mandi } & \text { K-S-P } \\ \text { Bari ia laus } & \text { Semalam dia pergi } & \text { K-S-P }\end{array}$

\section{Findings of the Study}

\section{Positive Sentence :}

(1) Pakpak: Ning laus kami mi Pakpak

Meaning in Bahasa: Kami mau pergi ke Pakpak

On the positive clause, there is a change in position of the verb. If in Bahasa the verb is presented after the subject, then in Pakpak language, which preceded the sentence is a verb. We can see it from the previous example.

\section{Negative Sentence :}

口 (verb) $>$ the word negation in front of the sentence

(2) Pakpak: oda ku pangan nakan 


\section{Meaning in Bahasa: Aku tidak makan nasi}

The example of a negative sentence in the form of a verb, there is a change in the position of the word. The use of the word negation is usually presented after the subject and followed by the word verb, then in Pakpak language, its position changes, it is where the negation comes first on the start to emphasize.

(nominal) $>$ the subject remains in front

(3) Pakpak: aku oda sada guru i

Meaning in Bahasa: Saya bukan seorang guru.

For nominal in negative sentences that describe adjective or noun, then no position changes are made. The writing rules are still the same as those which often used in Bahasa.

\section{Interrogative Sentence}

In interrogative sentences, the types of sentence are divided into two, namely WH question and yes / no question. WH-question is a question that is started with a question word and the answer is an explanation. Meanwhile, yes/no question is a question that is began with auxilary verb by presenting only two answers, i.e. or not.

\section{a.WH-question:}

(Verb)

(4) Pakpak: kade ngo sinidokken ndene ndai?

Meaning in Bahasa: Apa yang kamu lakukan barusan?

In the example of the verb in the wh question sentence type, the systematics follows as the same as the rules in Bahasa. Then the question word is always located at the beginning of the sentence as an opening on the message followed by a high note to ask something.

\section{b. Yes /No question:}

\section{$\square \quad$ Nominal (adjective)}

(5) Pakpak: mberru ma ngo aku

Meaning in Bahasa: apakah aku cantik? (noun)

- Nominal (noun)

(6) Pakpak: sada kalak dokter ngo ko?

Meaning in Bahasa: apakah kamu seorang dokter?

In the form of the sentence yes / no question in the Pakpak language system, the rule has its own rules, it is either noun or verb is always begin with what points are intended to be used as an example. So, the one who pays the initial phrase in the sentence is the one who is in the Pakpak language called Mberru. This also applies to sentences whose begin with a noun beginning with the definite article 'sada' or one.

- $\quad$ Verb

(7) Pakpak: mi juma ngo ko?

Meaning in Bahasa: Apa kau pergi ke ladang? 
(8) Pakpak: mulak ngo ia ceggen i?

Meaning in Bahasa: apakah dia pulang tadi pagi?

(9) Pakpak: Enggo ngo soh kalak i?

Meaning in Bahasa: Apakah mereka sudah sampai?

(10) Pakpak: boi ngo iurupi ko aku ?

Meaning in Bahasa: bisakah kamu menolongku?

For sentence (7), (8),(9), and (10), the four data above prove that in any way, the Pakpak language still does not have a 'what' vocabulary. So, the use of the word what in Pakpak language is replaced with the sentence that the speaker wants to convey. In the form of any sentence, it is still preceded by adjectives, nouns, verbs, or auxilary verbs and modals which are points to be pronounced as a sentence by the speaker.

\subsection{Relationship between Thinking, speaking, and Culture in Pakpak Simsim Language}

Based on the analysis of sentence structure in Pakpak language, we found positive or affirmative sentences that provide information, the position of the verb lies at the beginning of the sentence. The subject position is placed after the verb. Based on these facts, it can be concluded that the Pakpak society is a population that emphasizes action. They try to be objective by seeing what is done by a subject. So, the first thing in their mind starts from the word 'what' because this requires a significant answer. When Pakpak people convey information based on their ability to speak, this has become a custom that has been agreed upon. So, they are accustomed to start a conversation by focusing on the main points or goals in a speech by putting what they think as the point of conversation when talking to each other. Therefore, the information points can be verbs, adjectives, nouns, or even forms of auxilary verbs and modals. It depends on what the purpose of the communication is.

\section{Conclusion}

The character of the Pakpak society influences the way they speak. Likewise, the mindset of the Pakpak ethnic is clear from the words they use:

1. Postion of verbs at the beginning of the sentence indicates that Pakpak society have an objective character.

2. The absence of "what" vocabulary in interrogative sentences (Yes / no questions) proves that Pakpak people have character to the point. (not long-winded)

3. The Pakpak ethnic has a special vocabulary on the term planting rice because their main livelihood is farming.

4. Because of the influence of geographical location, the place of residence of the Pakpak society has a flat-toned speech. This is because the location of each family is parallel and near together.

5. Pakpak simsim society only knows two expressions, namely thank you and help.

\section{References}

[1] L. Bloomfield, Language, Twelfh Impression. Great Britain: Cox and Wyman Lfd, 1958.

[2] Z. Dörnyei, The Psychology of the Language Learner: Individual Differences in Second 
Language Acquisition. Mahwah, New Jersey, London: Lawrence Erlbaum Associates, 2005.

[3] K. A. Harras and B. A. Dutha, Dasar-dasar Psikolinguistik. Bandung: Upi Press, Putaka Budi Digital, 2009.

[4] V. Listianingrum, "An Error Analysis on Simple Past Tense Made by Second Grade Students in their Stories (A Psycholinguistics Approach)," Sebelas Maret University, 2013.

[5] E. Sapir, Language: An Introduction to the Study of Speech, vol. 15, no. 18. New York: Harcourt, Brace, 1921.

[6] B. J. Fraser and K. G. Tobin, International Handbook of Science Education, no. 2. Netherland: Springer, 1998.

[7] B. L. Whorf, Language, Thought, and Reality. Cambridge: Technology Press of Massachusetts Institute of Technology, 1956.

[8] Jalaluddin Rakhmat, Psikologi Komunikasi. Bandung: Remaja Rosdakarya, 2014.

[9] S. A. Mu'min, “Teori Perkembangan Kognitif Jean Piaget,” J. Al-Ta'dib, vol. 6, no. 1, pp. 89-99, 2013.

[10] I. Landau, "The locative syntax of experiencers," in Linguistic Typology, vol. 15, no. 1, Cambridge, Massachusetts, London: The MIT Press, 2011, pp. 123-130.

[11] H. Kridalaksana, Struktur, kategori, dan fungsi dalam teori sintaksis. Jakarta: Universitas Katolik Indonesia Atma Jaya, 2002.

[12] J.s Badudu, Inilah Bahasa Indonesia yang Benar. Jakarta: Gramedia Pustaka Utama More Details... GENRES, 1994.

[13] H. G. Tarigan, Menulis Sebagai Suatu Keterampilan Berbahasa. Bandung: IKIP Bandung, 2008.

[14] H. Alwi, S. Dardjowidjojo, H. Lapoliwa, and A. M. Moeliono, Tata Bahasa Baku Bahasa Indonesia. Jakarta: Balai Pustaka, 2003.

[15] K. E., Kompetensi Ketatabahasaan dan kesusastraan Cermat Bahasa Indonesia. Bandung: Bandung Yrama Widya, 2004.

[16] I. B. Putrayasa and A. Susana, Kalimat Efektif: (Diksi, Struktur, dan Logika). B: Refika Aditama, 2007.

[17] H. Kridalaksana, Kelas Kata dalam Bahasa Indonesia, 2nd ed. PT. Gramedia Pustaka Utama, 2007.

[18] M. Ramlan, Ilmu Bahasa Indonesia: Sintaksis. Yogyakarta: U.P. Karyono, 1981.

[19] Sudaryono, Negasi dalam Bahasa Indonesia: Suatu Tinjauan Sintaktik dan Semantik. Jakarta: Pusat Pembinaan dan Pengembangan Bahasa, 1992.

[20] F. Rasul, "Bentuk-Bentuk Negasi Bahasa Muna," J. Humanika, vol. 2, no. 16, pp. 119, 2016.

[21] M. C. A. Sembiring, T. Aiyub, R. Amillah, and P. Perangin-angin, Morfologi dan Sintaksis Bahasa Pakpak Dairi. Departemen Pendidikan dan Kebudayaan, 1993. 